\title{
Brazil forced to cut back science funding
}

[LONDON] The Brazilian government is expected to announce major cuts to the country's science budget this week including a block on all new fellowships and research grants - as part of its response to the international financial crisis.

A broad package of fiscal measures has been drawn up following talks between the government and the International Monetary Fund, which are due to culminate with a set of economic measures designed to help Brazil weather its approaching economic recession.

Science and technology have not been spared from a wide swath of cuts to public spending. The Ministry of Science and Technology is being required to make cuts of at least 248 million réals (US\$208 million) in this year's budget, 20 per cent of its planned total of R $\$ 1.2$ billion.

The National Council for Scientific and Technological Development (CNPq), the main research funding agency, is expected to see its budget reduced by about $\mathrm{R} \$ 50$ million from the current level of $\mathrm{R} \$ 436$ million.

Oskar Klingl, chef de cabinet to Brazil's science minister, Israel Vargas, says the difficult situation facing science is now unavoidable. The budget cuts for 1998 are already known, but uncertainty still hangs over what is likely to happen next year.

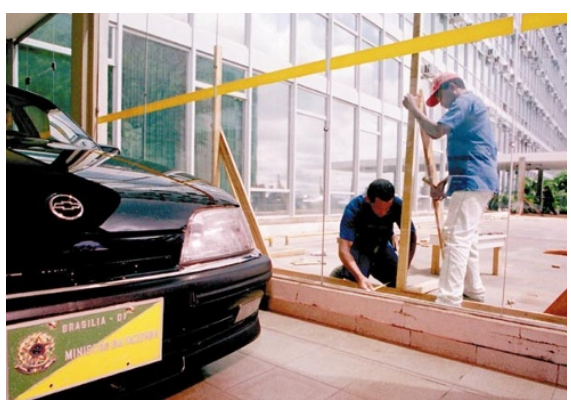

Brazil's Finance Ministry was under repair last week as it moved to meet the IMF's demands.

In addition to the cuts at the $\mathrm{CNPq}$, other budget reductions will have a direct impact on the activities of the 14 research institutions run by the science ministry.

The situation has spread alarm in the scientific community. Last week a public protest in Rio de Janeiro led by the Brazilian Society for the Development of Science (SBPC) brought together scientists representing more than 30 organizations.

Their main concern is for the future of the $\mathrm{CNPq}$, the main source of funding for university research. Two weeks ago, the CNPq circulated internally a list of proposed economy measures, signed by its president, Jose Galizia Tundisi, that included freezing the approval of practically all new fellowships, research grants and cooperative agreements.

A senior $\mathrm{CNPq}$ official says the measures have been carefully considered, and that the agency tried to ensure that the cuts did the minimum damage. All formal commitments will be met, and fellowships that have already been granted will be funded.

But this has done little to reassure scientists. Last week's protest culminated with the release of two statements, one directed to the Brazilian nation and the other to the international scientific community, attacking what the protesters described as the government's lack of interest in science and technology.

Scientists have called for Tundisi's resignation, complaining that he failed to discuss the agency's financial difficulties with the scientific community, but merely drew up the internal list of economy measures. The protests were triggered by the 'leak' of this list.

Many scientists fear that their position will become even more difficult after the release of this week's austerity package. The SBPC has created a forum on its website for discussion of the topic. Messages of support have been received from scientists in other Latin American countries, many of whom share similar concerns about their own countries' science budgets. AndreaKauffman-Zeh

\section{Clash over demand for more synchrotron sources in Europe}

[PARIS] Simmering frustration among French synchrotron researchers over the government's reluctance to finance the construction of a third generation facility boiled over this week. Staff at the national synchrotron facilities accused the science minister, Claude Allègre, of making misleading statements to the National Assembly on the need for a new facility.

Plans for a FF1 billion (US\$182 million) 2.15-GeV source, Soleil, to replace the ageing LURE facilities near Paris $(800 \mathrm{MeV}$ and 1.85 $\mathrm{GeV}$ ), have received backing from Catherine Bréchignac, director general of the Centre National de la Recherche Scientifique and Yannick d'Escatha, head of the French Atomic Energy Commission (see Nature 390, $212 ; 1997)$. But the scheme has been frozen by Allègre as part of a review of big science spending.

The French proposal was 'strongly endorsed' in a report on European synchrotron radiation, issued last week by an independent panel of the European Science Foundation. The report warned that, unless new sources were built, Europe "risked losing its lead in certain aspects of biological and biomedical research".

Synchrotron radiation is used by scientists from many disciplines to reveal the structure of biological molecules. The panel points out that demand will increase as the plethora of genome projects creates a need to determine more protein structures.

But in the French National Assembly last week Allègre argued that Europe had a surplus of synchrotron facilities. "Within two years there will be seven thirdgeneration synchrotrons in Europe," he said. "There are two in the United States. Do you really think we need an eighth without a preliminary inquiry? Do you know an area where Europe needs four times as many machines as the United States?"

Allègre reiterated his view that most big science facilities should be European, and that national facilities should be the exception. He also asserted that Soleil would provide employment for only 40 people, and that the construction of synchrotrons in Germany and Italy would free user time at the European Synchrotron Radiation Facility (ESRF) in Grenoble, France.

Allègre spoke in response to questions from Pierre Lasbordes, a member of the neo-Gaullist RPR party, whose Essonne constituency is home to LURE and a candidate to host Soleil. Lasbordes said that the Paris region agreed last year to pay more then half the costs of a new machine.
"We are only waiting for you," said Lasbordes, describing Soleil as "indispensable". The delays were "all the more regrettable" given that new facilities were being built in several European countries, including the United Kingdom.

LURE's director Robert Comés and senior staff at the facility have written to Allègre, claiming that his declaration to parliament was inaccurate, and showed his "lack of knowledge" of the project. They claim the United States has plans to increase its number of synchrotron sources to seven.

The researchers contest the need for a further inquiry into the case for Soleil, arguing that it has been approved by several assessments over the past seven years. The letter challenges Allègre's estimate of employment at the facility, pointing out that LURE itself employs 350 full time staff, and is used by almost 2,000 researchers annually.

It also challenges Allègre's claim that the refurbishment of Italian and German facilities will free user time at ESRF, adding that soft radiation produced by Soleil will find different applications to the hard X-rays from the 6-GeV ESRF machine. The letter also points out that France's share of user time already exceeds its financial participation in the ESRF. Declan Butler 